\title{
Enhanced NK cell adoptive antitumor effects against breast cancer in vitro via blockade of the transforming growth factor- $\beta$ signaling pathway
}

This article was published in the following Dove Press journal:

OncoTargets and Therapy

22 June 2015

Number of times this article has been viewed

\author{
Yue Zhaol,* \\ Jinyue $\mathrm{Hu}^{2, *}$ \\ Rongguo $\mathrm{Li}^{\prime}$ \\ Jian Song' \\ Yujuan Kang' \\ Si Liu' \\ Dongwei Zhang' \\ 'Department of General Surgery, \\ Second Affiliated Hospital of \\ Harbin Medical University, Harbin, \\ ${ }^{2}$ Department of Breast and Thyroid \\ Surgery, The Third Hospital of \\ Zhengzhou, Zhengzhou, People's \\ Republic of China \\ *These authors contributed equally \\ to this work
}

\begin{abstract}
Natural killer (NK) cells have great potential for improving cancer immunotherapy. Adoptive NK cell transfer, an adoptive immunotherapy, represents a promising nontoxic anticancer therapy. However, existing data indicate that tumor cells can effectively escape NK cellmediated apoptosis through immunosuppressive effects in the tumor microenvironment, and the therapeutic activity of adoptive NK cell transfer is not as efficient as anticipated. Transforming growth factor-beta (TGF- $\beta$ ) is a potent immunosuppressant. Genetic and epigenetic events that occur during mammary tumorigenesis circumvent the tumor-suppressing activity of TGF- $\beta$, thereby permitting late-stage breast cancer cells to acquire an invasive and metastatic phenotype in response to TGF- $\beta$. To block the TGF- $\beta$ signaling pathway, NK cells were genetically modified with a dominant-negative TGF- $\beta$ type II receptor by optimizing electroporation using the Amaxa Nucleofector system. These genetically modified NK cells were insensitive to TGF- $\beta$ and resisted the suppressive effect of TGF- $\beta$ on MCF-7 breast cancer cells in vitro. Our results demonstrate that blocking the TGF- $\beta$ signaling pathway to modulate the tumor microenvironment can improve the antitumor activity of adoptive NK cells in vitro, thereby providing a new rationale for the treatment of breast cancer.
\end{abstract}

Keywords: transforming growth factor-beta, natural killer cells, breast cancer, adoptive immunotherapy

\section{Introduction}

Breast cancer is one the most frequent cancers occurring in women in the developed world. The worldwide incidence of breast cancer has significantly increased within the past several decades, and in the People's Republic of China, it is the most common invasive cancer in women. ${ }^{1}$ To date, surgery, chemotherapy, radiotherapy, and endocrine therapy have generated greatly improved clinical outcomes; however, breast cancer is recurrent and metastasizes. Therefore, identifying more effective and safer therapeutic modalities is necessary. The immune system plays a dual role in breast cancer. It promotes tumorigenesis through inflammatory pathways and also suppresses adaptive immunity and prevents tumor formation through active immune surveillance. Consistent with this duality, some breast cancer patients display clear evidence of immune suppression.

Natural killer (NK) cells are key components of the innate immune system and play a critical role in the early host defense against viral, bacterial and other infections, as well as cancer. They exert their effector function via direct killing of virally infected cells and tumor cells and via production of immunoregulatory cytokines and chemokines, thereby effecting adaptive immune responses. ${ }^{2-4}$ However, the adoptive
Correspondence: Dongwei Zhang Department of General Surgery, Second Affiliated Hospital of Harbin Medical University, 246 Xuefu Road, Nangang District, Harbin I50086,

People's Republic of China

Tel +86 I350484 5465

Email mugong0@163.com 
transfer of NK cells in solid tumors appear to have a less robust response, likely because of the numerous activating and inhibitory stimuli that act on NK cells, the immunosuppressive effect in the tumor environment, and insufficient infiltration of activated NK cells. ${ }^{5,6}$ As a result, overcoming active immune suppression in the tumor microenvironment is an important consideration for adoptively transferred NK cells.

Transforming growth factor-beta (TGF- $\beta$ ) functions as both a tumor suppressor and promoter. In many earlystage tumors, TGF- $\beta$ is a potent inducer of growth arrest. However, TGF- $\beta$ promotes cell motility, invasion, and metastasis in advanced tumors. ${ }^{7}$ TGF- $\beta$ is also a potent tumor suppressor that has a negative impact on surrounding host immune cells in the tumor microenvironment. ${ }^{8,9}$ The levels of TGF- $\beta$ are often elevated in the serum of cancer patients and this is associated with systemic inhibition of immune function, including weakened NK cell responses, and is also associated with a poor prognosis. ${ }^{10-12}$ In this study, we demonstrate that blocking the TGF- $\beta$ signaling pathway to modulate the tumor microenvironment improves the antitumor activity of adoptive NK cells in vitro, thereby providing a new rationale for the treatment of breast cancer.

\section{Materials and methods}

\section{Cell lines}

The MDA-MB231 human breast cancer cell line and T47D cell line were obtained from the Shanghai Cell Bank of the Chinese Academy of Sciences (Chinese Academy of Sciences, Shanghai, People's Republic of China). The human breast cancer MCF-7 cell line was obtained from the laboratory of the Second Affiliated Hospital of Harbin Medical University. The cells were maintained in a $5 \% \mathrm{CO}_{2}$ humidified incubator at $37^{\circ} \mathrm{C}$. NK cells were obtained from the American Type Culture Collection Cell Bank (Beijing, People's Republic of China). NK cells and nucleofected NK cells (Amaxa, Cologne, Germany) were maintained in Alpha Minimum Essential Medium (Invitrogen, Grand Island, NY, USA) without ribonucleosides and deoxyribonucleosides but with $2 \mathrm{mM}$ L-glutamine and $1.5 \mathrm{~g} / \mathrm{L}$ sodium bicarbonate. A complete growth medium was prepared by addition of $12.5 \%$ horse serum (Invitrogen) and $12.5 \%$ fetal bovine serum, $0.2 \mathrm{mM}$ inositol, $0.1 \mathrm{mM}$ 2-mercaptoethanol, $0.02 \mathrm{mM}$ folic acid, and 1,000 U/mL recombinant interleukin-2 (all from Sigma-Aldrich, St Louis, MO, USA). Frozen stocks of the cell lines were thawed every 2 months for in vitro assays.
Construction of PTAR-GET-DNT $\beta$ RII eukaryotic expression vector

TGF- $\beta$ was first combined with the type II TGF- $\beta$ receptor (T $\beta$ RII) to activate the downstream pathway through transfection of dominant-negative T $\beta$ RII (DNT $\beta$ RII) to block the TGF- $\beta$ signaling pathway and restore the killing effect of NK cells. DNT $\beta$ RII was amplified by polymerase chain reaction (PCR). The forward primer was 5'-ATGCTTCT CGAGATGGGTCGGGGGCT-3' and the reverse primer was 5'-CTGAATTCCTACTGCCGGTTAACGCTGA-3'. The XhoI and EcorI restriction enzyme site were imported on the end of sequence respectively and synthesized the objective gene oligo by Gene2Oliga software. The product was subcloned into the corresponding restriction site in the eukaryotic expression vector, pTAR-GET (Invitrogen). DNA sequencing analysis confirmed the sequence of the plasmid (Settlebio, Harbin, People's Republic of China). NK/pTAR-GET cells were transferred by a total of $5 \times 10^{5} \mathrm{NK}$ cells were placed in $0.1 \mathrm{~mL}$ electroporation solution with $2 \mu \mathrm{g}$ pTAR-GET and nucleofected using the Nucleofector program.

\section{Analysis of TGF- $\beta$ I expression in three breast cancer cell lines}

TGF- $\beta 1$ (RapidBio, Dallas, TX, USA) expression in the MDA-MB231, T47D, and MCF-7 human breast cancer cell lines was detected by enzyme-linked immunosorbent assay (CusaBio, Wuhan, People's Republic of China). MCF-7, MDA-MB231, and T47D cell counts were obtained after 2 days. A total of $5 \times 10^{5}$ cells for each cell line were placed in six-well plates with $2 \mathrm{~mL}$ of culture solution per well. The culture supernatant was collected into a sterile tube after cell culture for 48 hours and centrifuged for 20 minutes. The supernatant was measured at an absorbance of $450 \mathrm{~nm}$.

\section{$\mathrm{T} \beta \mathrm{R}$ expression in NK cells}

Cells were stained with phycoerythrin-conjugated monoclonal antibody against the TGF- $\beta$ type I receptor and TGF- $\beta$ type II receptor (Santa Cruz Biotechnology, Santa Cruz, CA, USA). They were then stained with a fluorescein isothiocyanate-conjugated monoclonal antibody against CD56 (Santa Cruz). The cells were analyzed using a FACScan flow cytometer (Beckman Coulter, Brea, CA, USA).

\section{Gene transfection of NK cells and DNT $\beta R$ II expression in NK cells}

NK cells were genetically transferred using the Amaxa Nucleofector system. A total of $5 \times 10^{5} \mathrm{NK}$ cells were placed 
in $100 \mu \mathrm{L}$ of electroporation solution with $2 \mu \mathrm{g}$ pTAR-GETDNT $\beta$ RII and nucleofected using the Nucleofector program. Total RNA was extracted from the DNT $\beta$ RII-NK cells using Trizol, and reverse transcription (RT)-PCR was used to determine the expression of DNT $\beta$ RII. A total of $1 \times 10^{7} \mathrm{NK}$ pTAR-GET-DNT $\beta R I I$, parental NK cells, and NK/pTARGET cells were transferred over 24 hours at $37^{\circ} \mathrm{C}$. The cells were centrifuged at 1,000 rpm for 5 minutes and collected in a $1.5 \mathrm{~mL}$ centrifuge tube. Each tube contained $1 \times$ phosphatebuffered saline and the suspension cells at $37^{\circ} \mathrm{C}$. The cells were then centrifuged at 1,000 rpm for 5 minutes, and the supernatant was collected. This was repeated once. The 475 $\mathrm{nm}$ excitation wavelength was selected and the cells were observed under an inverted fluorescence microscope.

\section{Western blotting for Smad-2 and Smad-3 phosphorylation}

To determine Smad-2 and Smad-3 protein (Cell Signaling, Danvers, MA, USA) expression in parental NK, NK-pTARGET, and NK-pTAR-GET-DNT $\beta$ RII cells, NK cells were treated with or without $10 \mathrm{ng} / \mathrm{mL}$ TGF- $\beta 1$ for 16 hours before harvesting. Western blotting was used to detect the phosphorylation status of Smad-2 and Smad-3. The blots were stripped and reprobed with anti-glyceraldehyde-3-phosphate dehydrogenase monoclonal antibody (Cell Signaling) to confirm equal loading.

\section{CCK-8 assays in vitro}

A Cell Counting Kit-8 (CCK-8) was purchased from Dojindo Chemical Research Institute (Shanghai, People's Republic of China). We divided the MCF-7 cells into five groups as follows: NK + MCF-7 (group 1), NK + MCF-7 + TGF- $\beta 1$ (group 2), NK/pTAR-GET-DNT $\beta$ RII + MCF-7 + TGF- $\beta 1$ (group 3), NK/pTAR-GET + MCF-7 + TGF- $\beta 1$ (group 4), and NK/ pTAR-GET-DNT $\beta$ RII + MCF-7 (group 5). The concentration of TGF- $\beta 1$ used in our study was $10 \mathrm{ng} / \mathrm{mL}$. The Cell Counting Kit-8 was used to measure the activity of the NK cells. Effector and target cells were incubated at effector to target ratios of 1:1, 10:1, and 20:1 for 4 hours before the supernatants were harvested and analyzed on a gamma counter.

\section{Statistical analysis}

All data are presented as the mean \pm standard deviation. Statistical comparisons were performed using one-way analysis of variance. The statistical analysis was performed using the Statistical Package for the Social Sciences version 10.0 software (SPSS Inc, Chicago, IL, USA). All $P$-values $<0.05$ were considered to be statistically significant.

\section{Results DNT $\beta$ RII expression in NK cells}

Expression of T $\beta R I$ and T $\beta R I I$ in the NK cells was detected by fluorescence-activated cell sorting. Both T $\beta R I$ and T $\beta R I I$ were highly expressed in the parental NK cells (Figure 1). DNT $\beta$ RII was amplified by PCR (Figure 2A). Expression of pTAR-GET-DNTRRII in the nucleofected NK cells was confirmed by RT-PCR (Figure 2B) because of the presence of a 650 base pair DNA fragment. Expression of GET in the NK cells was observed by fluorescence microscopy (Figure 2C).

\section{TGF- $\beta$ I expression in three breast cancer cell lines}

The results for TGF- $\beta 1$ expression in the human breast cancer cell lines MCF-7, MDA-MB23, and T47D were $123.61 \pm 10.32 \mathrm{pg} / 10^{5}, 85.72 \pm 9.01 \mathrm{pg} / 10^{5}, 37.56 \pm 2.64 \mathrm{pg} / 10^{5}$, respectively. The MCF-7 cell line secreted the highest level of TGF- $\beta 1$, whereas the lowest was in the T47D cell line $(P<0.001$, Table 1$)$. We selected the MCF-7 cell line to incubate with TGF- $\beta 1$.

\section{Transfection of pTAR-GET-DNT $\beta$ RII plasmid prevents Smad-2 and Smad-3 protein phosphorylation}

Western blotting showed that without TGF- $\beta$, the parental NK cells, NK/pTAR-GET cells, and NK/pTAR-GETDNT $\beta$ RII cells had visible Smad-2 and Smad-3 protein expression (Figure 3 ). After adding TGF- $\beta$ to the parental NK cells, NK/pTAR-GET cells, and NK/pTAR-GET-DNT $\beta$ RII cells, the results showed TGF- $\beta$-mediated phosphorylation of Smad-2 and Smad3 as determined by Western blotting in the parental NK cells and NK-pTAR-GET cells, but not in the NK/pTAR-GET-DNT $\beta$ RII cells (Figure 3). As a result, the nucleofection of pTAR-GET-DNT $\beta$ RII attenuated Smad-2 and Smad-3 phosphorylation in the stably transfected NK cells after treatment with TGF- $\beta 1$, suggesting that the TGF- $\beta$ signaling pathways can be blocked by nucleofection of pTAR-GET-DNT $\beta$ RII.

\section{Effect of blocking TGF- $\beta$ signaling in NK cells in vitro}

To confirm the immunosuppressive effect of TGF- $\beta$ on NK cells, the antitumor activity was compared between parental NK cells incubated with or without TGF- $\beta 1$. NK cells incubated with TGF- $\beta 1$ showed less cytotoxicity against MCF-7 cells than those without TGF- $\beta 1$ (Table 2). All $P$-values were $<0.001$. We also compared the killing activity of NK/ pTAR-GET-DNTRRII cells and NK/pTAR-GET cells in 

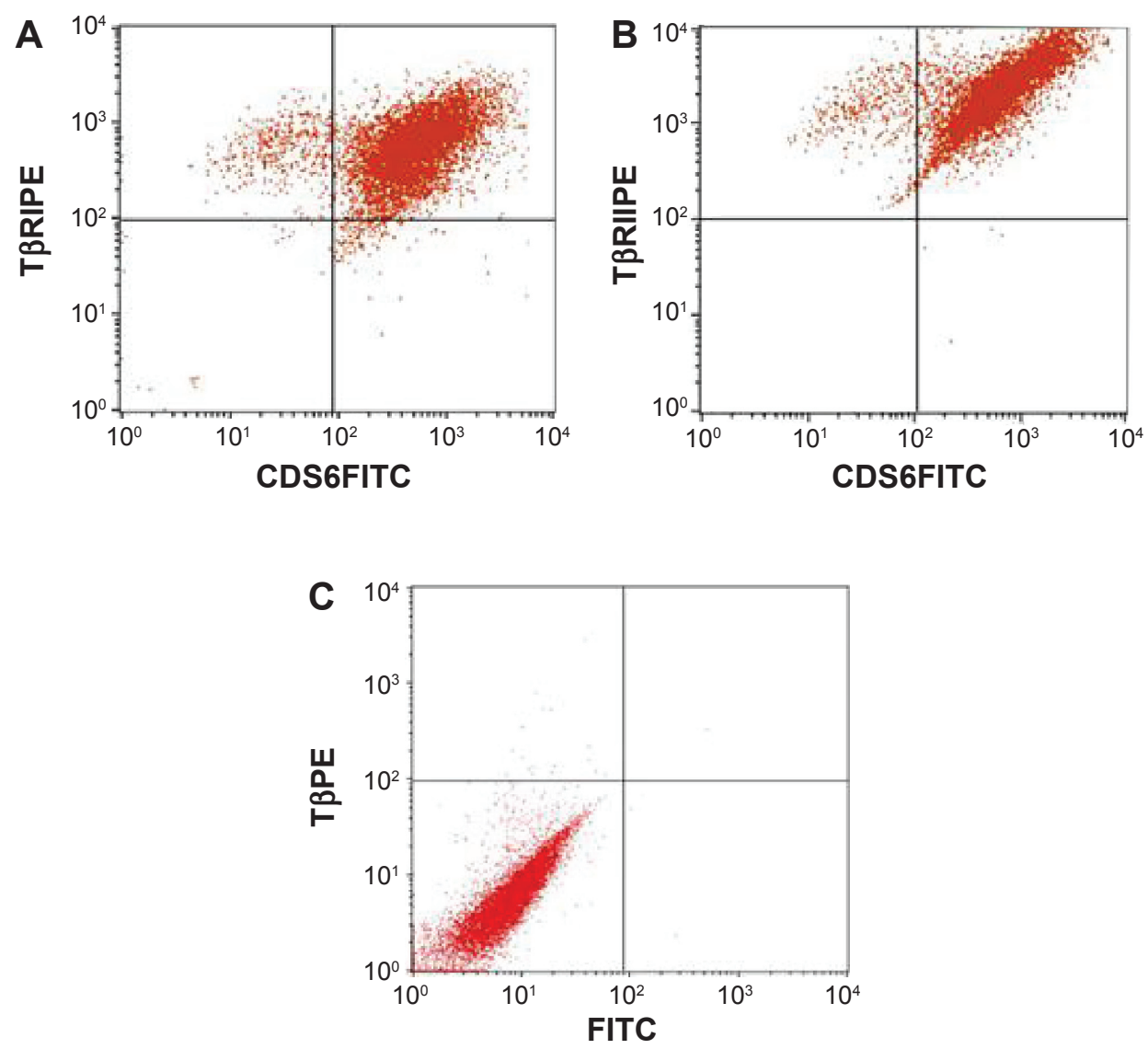

Figure I Expression of T $\beta R I$ and T $\beta R I I$, respectively, in NK cells detected by FACS.

Notes: (A) Expression of T $\beta R I$ in NK cells detected by FACS. (B) Expression of T $\beta R$ Il in NK cells detected by FACS. (C) PE/fluorescein isothiocyanate controls detected by FACS. Abbreviations: FACS, fluorescence activated cell sorting; PE, phycoerythrin; NK, natural killer; T $\beta$ RII, TGF- $\beta$ type II receptor; T $\beta R$, TGF- $\beta$ type I receptor; TGF- $\beta$, transforming growth factor-beta; FITC, fluorescein isothiocyanate.

vitro, and the killing activity of NK/pTAR-GET-DNT $\beta$ RII cells was higher (Table 3). All $P$-values were $<0.001$. To determine if the transfection of pTAR-GET-DNT $\beta$ RII can affect the killing activity of NK cells, we compared the killing rate between group 1 and group 5 , and found that transfection of DNT $\beta$ RII into NK cells did not change its internal killing activity (Table 4$)$. None of the $P$-values were statistically significant $(P>0.05)$.

\section{Discussion}

Breast cancer is immunogenic, and infiltrating immune cells in primary breast tumors provide important clinical, prognostic, and predictive information. ${ }^{13}$ The immune system plays a dual role in breast cancer, both by promoting tumorigenesis through inflammatory pathways and by suppressing adaptive immunity and preventing tumor formation through active immune surveillance. Notably, the presence of immune cells in breast cancers also exerts an antitumor effect and predicts a favorable response to cancer therapy. ${ }^{14,15}$ Different types of infiltrating immune cells have distinct prognostic and predictive significance. As part of this network, nonspecifically acting NK cells, antigen-presenting cells, and cells of the adaptive immune compartment could, by combining their functions, generate persistent antitumor immune memory responses. NK cells are important components in bridging innate and adaptive immunity. However, immune cells of the tumor microenvironment also directly suppress NK cells.

TGF- $\beta$ is normally overexpressed in the tumor microenvironment and is negatively correlated with tumor progression and patient prognosis. ${ }^{16}$ TGF- $\beta 1$ can trigger the generation of immune-suppressive regulatory T-cells in situ that are associated with reduced survival in estrogen receptor-positive breast tumors. There is evidence that the inhibitory effect of TGF- $\beta$ signaling on antitumor T-cells can be blocked by use of a dominant-negative TGF- $\beta$ receptor expressed on T-cells themselves. ${ }^{17}$ Increased production of TGF- $\beta$ may cause immunosuppression, extracellular matrix degradation, epithelial to mesenchymal transition, and neoangiogenesis that promotes tumor cell invasion and metastasis. ${ }^{18,19}$ In humans, 


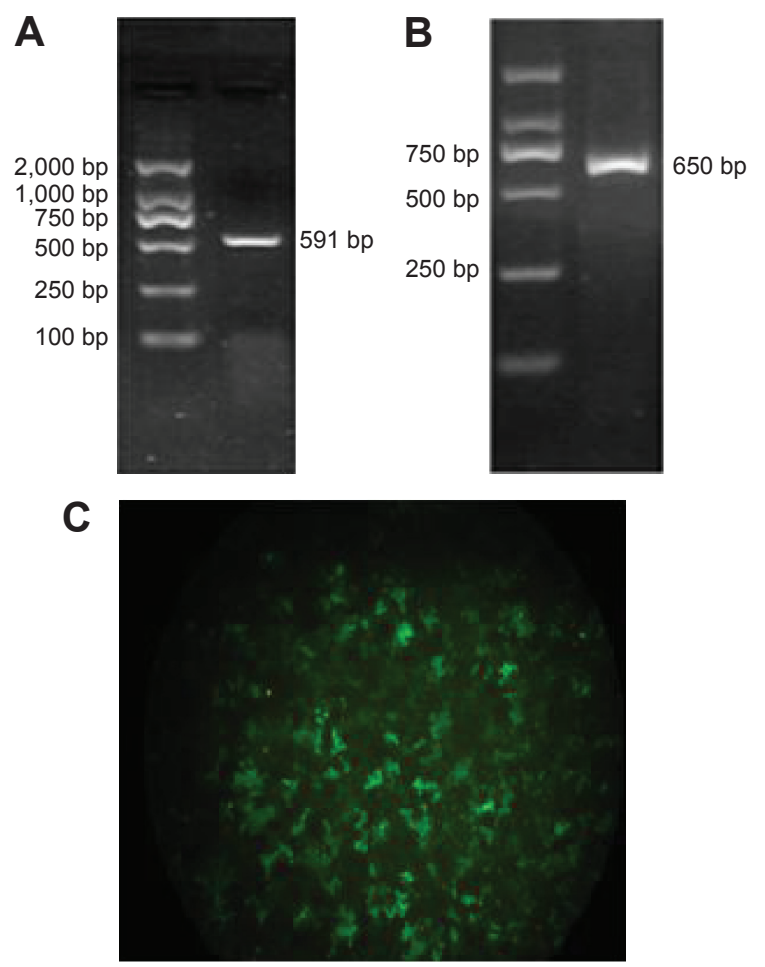

Figure 2 Genetic modification of NK cells with DNT $\beta$ RII.

Notes: (A) Amplification of the DNTßRIl gene in a 59l bp DNA fragment. (B) Electrophoretic analysis showed the presence of a DNA fragment in a $650 \mathrm{bp}$ by RT polymerase chain reaction. (C) Expression of GET in NK cells observed by fluorescence microscopy.

Abbreviations: bp, base pair; NK, natural killer; DNT $\beta$ RII, dominant-negative TGF- $\beta$ type II receptor; TGF- $\beta$, transforming growth factor-beta; RT, reverse transcription.
Table I TGF- $\beta$ I expression in three breast cancer cell lines

\begin{tabular}{lll}
\hline Group & TGF- $\beta I\left(p g / 10^{5}\right)$ & $P$-value \\
\hline MCF-7 & $123.61 \pm 10.32$ & $<0.001$ \\
MDA-MB 23I & $85.72 \pm 9.01$ & \\
T47D & $37.56 \pm 2.64$ & \\
\hline
\end{tabular}

Note: The data are shown as the mean \pm standard deviation.

Abbreviation: TGF- $\beta$ I, transforming growth factor- $\beta$ I.

circulating TGF- $\beta$ levels correlate with a poor prognosis in several cancer types, and this is related to reduced NK cell activity and, in particular, reduced expression of NK cells. ${ }^{10,12,20}$ The purpose of this study was to block the TGF- $\beta$ signaling pathway to modulate the tumor microenvironment and improve the antitumor activity of adoptive NK cells in vitro.

The canonical TGF- $\beta$ signaling pathway is activated upon binding of TGF- $\beta$ family members to T $\beta$ RII. In our study, we synthesized the gene for human DNT $\beta$ RII by PCR amplification and constructed the pTAR-GETDNT $\beta$ RII eukaryotic expression vector. DNT $\beta$ RII does not contain the Ser/Thr kinase domain structure; therefore, it can also combine with T $\beta$ RII, but cannot initiate the downstream signaling pathways..$^{21,22}$ In addition, peptide chains, which express a high number of DNT $\beta$ RII, transfer to the cell membrane and competitively inhibit normal T $\beta$ RII to block the TGF- $\beta$ signaling pathways. We tested

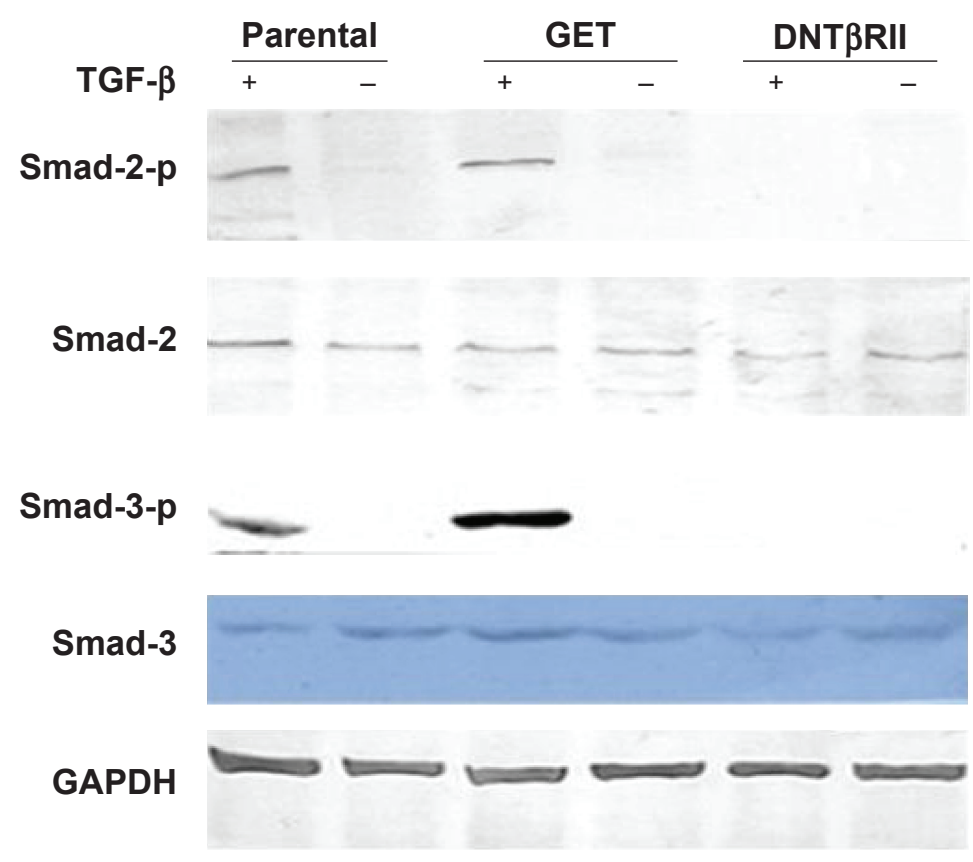

Figure 3 Transfection of PTAR-GET-DNT $\beta$ RII plasmid prevents phosphorylation of Smad-2 and Smad-3 protein in NK cells. Nucleofection with pTAR-GET-DNT $\beta$ RII plasmid inhibited Smad-2 and Smad-3 phosphorylation in TGF- $\beta$-treated NK cells. TGF- $\beta$-mediated phosphorylation of Smad- 2 and Smad-3 was observed by Western blotting in parental NK cells and in NK-GET cells but not in NK-DNT $\beta$ RII cells.

Abbreviations: NK, natural killer; TGF- $\beta$, transforming growth factor-beta; GAPDH, glyceraldehyde-3-phosphate dehydrogenase; DNT $\beta$ RII, dominant-negative TGF- $\beta$ type II receptor. 
Table 2 TGF- $\beta$ I inhibition and NK killing activity in MCF-7 cells

\begin{tabular}{llll}
\hline Group & \multicolumn{1}{l}{ Cytotoxicity (\%) } & \\
\cline { 2 - 4 } & I:I & I0:I & $\mathbf{2 0 : 1}$ \\
\hline With TGF- $\beta$ I (NK + MCF-7) & $8.27 \pm 0.62$ & $18.02 \pm 0.81$ & $27.34 \pm 1.20$ \\
Without TGF- $\beta$ I (NK + MCF-7) & $13.13 \pm 0.85$ & $33.27 \pm 0.96$ & $47.47 \pm 1.53$ \\
P-value & $<0.001$ & $<0.001$ & $<0.001$ \\
\hline
\end{tabular}

Note: The data are shown as the mean \pm standard deviation.

Abbreviations: NK, natural killer; TGF- $\beta$ I, transforming growth factor- $\beta$ I.

the expression level of TGF- $\beta 1$ in MCF-7, MDA-MB231, and T47D human breast cancer cell lines by enzyme-linked immunosorbent assay. All human breast cancer cell lines expressed TGF- $\beta 1$ in this study, indicating that TGF- $\beta 1$ exists in the tumor microenvironment. Expression of DNT $\beta$ RII in the nucleofected NK cells was confirmed by RT-PCR and GET fluorescence, and we also confirmed that NK cells contained high levels of T $\beta R I$ and T $\beta R I I$ and were therefore highly sensitive to the inhibitory effect of TGF- $\beta$.

Canonical TGF- $\beta$ signaling refers to signals transduced by activation of the latent transcription factors, Smad- 2 and Smad-3; therefore, canonical TGF- $\beta$ signaling is synonymous with Smad-dependent TGF- $\beta$ signaling. Ligand engagement of T $\beta$ RII leads to recruitment, phosphorylation, and activation of T $\beta R I$, which subsequently binds, phosphorylates, and stimulates Smad-2 and Smad-3,,$^{21,23}$ and imbalances in Smad-2/3 signaling contribute to oncogenic TGF- $\beta$ signaling. ${ }^{24-26}$ In our study, phosphorylation of Smad-2 and Smad-3 were not observed in NK cells modified by DNT $\beta$ RII compared with the TGF- $\beta$-mediated phosphorylation of Smad- 2 and Smad-3 as observed using Western blotting in parental NK cells and in NK/pTAR-GET cells. This indicates that transfer of the DNT $\beta$ RII vector blocked the TGF- $\beta$ signaling pathway of NK cells at the receptor level. NK cells incubated with TGF- $\beta 1$ exhibited less cytotoxicity toward MCF-7 cells compared with those without TGF- $\beta 1$ (Table 2), suggesting that TGF- $\beta 1$ inhibits the killing effect of NK cells in vitro. The killing activity of NK/pTAR-GET-DNT $\beta$ RII cells was higher than that of NK/pTAR-GET cells in vitro (Table 3). These results indicate that blocking TGF- $\beta$ signaling in NK cells opposes the inhibitory effect of TGF- $\beta$ in vitro, which is insensitive to TGF- $\beta$. However, the results in Table 4 indicate that transfection of DNT $\beta$ RII into NK cells did not change its internal killing activity. The results also indicate that, in the tumor microenvironment of TGF- $\beta$, transfection of DNT $\beta$ RII into NK cells enhances its antitumor effect by opposing the inhibitory effect of TGF- $\beta$ in vitro indirectly rather than by enhancing its intrinsic killing activity directly.

\section{Conclusion}

Our results indicate that DNT $\beta$ RII plasmid transfer blocks the TGF- $\beta$ signaling pathway in NK cells at the receptor level and that blocking TGF- $\beta$ signaling pathways in NK cells opposes the inhibitory effect of TGF- $\beta$ in vitro. Therefore, blocking the TGF- $\beta$ signaling pathway enhances NK cell adoptive antitumor effects against breast cancer in vitro. This outcome perhaps provides a new approach to overcome human breast cancer and may become a primary focus of development in the future. It may provide better quality of life for breast cancer patients and prolong overall survival time.

\section{Acknowledgments}

This work was supported by the Heilongjiang Province of Science and Technology (grant D201273), and Harbin Science and Technology Bureau (grant 2012RFQS064).

Table 3 Blocking TGF- $\beta$ signaling pathway overcomes immunosuppression by TGF- $\beta$ I in NK cells in vitro

\begin{tabular}{|c|c|c|c|}
\hline \multirow[t]{2}{*}{ Group } & \multicolumn{3}{|c|}{ Cytotoxicity (\%) } \\
\hline & $1: 1$ & $10: 1$ & 20:1 \\
\hline NK/DNT $\beta$ RII + MCF-7 + TGF- $\beta$ I & $\mid 1.34 \pm 1.01$ & $30.06 \pm 1.03$ & $46.07 \pm 1.31$ \\
\hline NK/GET + MCF-7 + TGF- $\beta$ I & $7.35 \pm 0.72$ & $15.67 \pm 0.92$ & $24.98 \pm 1.27$ \\
\hline$P$-value & $<0.001$ & $<0.001$ & $<0.001$ \\
\hline
\end{tabular}

Note: The data are shown as the mean \pm standard deviation.

Abbreviations: NK, natural killer; TGF- $\beta$ I, transforming growth factor- $\beta$ I; DNT $\beta$ RII, dominant-negative TGF- $\beta$ type II receptor. 
Table 4 Transfection of plasmid does not alter NK cell killing effects in vitro

\begin{tabular}{|c|c|c|c|}
\hline \multirow[t]{2}{*}{ Group } & \multicolumn{3}{|c|}{ Cytotoxicity (\%) } \\
\hline & I:I & 10:1 & 20:1 \\
\hline NK + MCF-7 & $13.03 \pm 0.67$ & $33.25 \pm 0.91$ & $47.08 \pm|.5|$ \\
\hline NK/DNT $\beta$ RII + MCF-7 & $|2.1| \pm 0.82$ & $32.17 \pm 1.35$ & $45.32 \pm 1.30$ \\
\hline$P$-value & 0.131 & 0.138 & 0.284 \\
\hline
\end{tabular}

Note: The data are shown as the mean \pm standard deviation.

Abbreviations: NK, natural killer; DNT $\beta$ RII, dominant-negative TGF- $\beta$ type II receptor; TGF- $\beta$, transforming growth factor- $\beta$.

\section{Disclosure}

The authors report no conflicts of interest in this work.

\section{References}

1. He DD, Wang CF, Cao LL, et al. Epidemic trend of female breast cancer incidence in Min Hang District, Shanghai. China Cancer. 2010;13: $108-110$.

2. Papamichail M, Perez SA, Gritzapis AD, Baxevanis C. Natural killer lymphocytes: biology, development, and function. Cancer Immunol Immunother. 2004;53:176-186.

3. Biron CA, Brossay L. NK cells and NKT cells in innate defense against viral infections. Curr Opin Immunol. 2001;13:458-464.

4. Herberman RB. Cancer immunotherapy with natural killer cells. Semin Oncol. 2002;29:27-30.

5. Hallett WH, Murphy WJ. Positive and negative regulation of natural killer cells: therapeutic implications. Semin Cancer Biol. 2006;16: 367-382.

6. Ngo MC, Rooney CM, Howard JM, Heslop HE. Ex vivo gene transfer for improved adoptive immunotherapy of cancer. Hum Mol Genet. 2011; 20:R93-R99.

7. Lee MY, Kim HJ, Kim MA, et al. Nek6 is involved in G2/M phase cell cycle arrest through DNA damage induced phosphorylation. Cell Cycle. 2008;7:2705-2709.

8. Wallace A, Kapoor V, Sun J, et al. Transforming growth factor- $\beta$ receptor blockade augments the effectiveness of adoptive T-cell therapy of established solid cancers. Clin Cancer Res. 2008;14: 3966-3974.

9. Kelly RJ, Morris JC. Transforming growth factor-beta: a target for cancer therapy. J Immunotoxicol. 2010;7:15-26.

10. Ikushima H, Miyazono K. TGF-beta signalling: a complex web in cancer progression. Nat Rev Cancer. 2010;10:415-424.

11. Friese MA, Wischhusen J, Wick W, et al. RNA interference targeting transforming growth factor-beta enhances NKG2D mediated antiglioma immune response, inhibits glioma cell migration and invasiveness, and abrogates tumorigenicity in vivo. Cancer Res. 2004;64:7596-7603.
12. Lee JC, Lee KM, Kim DW, Heo DS. Elevated TGF-beta1 secretion and down-modulation of NKG2D underlies impaired NK cytotoxicity in cancer patients. J Immunol. 2004;172:7335-7340.

13. Prat A, Perou CM. Deconstructing the molecular portraits of breast cancer. Mol Oncol. 2011;5:5-23.

14. Diaz-Montero CM, Salem ML, Nishimura MI, Garrett-Mayer E, Cole DJ, Montero AJ. Increased circulating myeloid-derived suppressor cells correlate with clinical cancer stage, metastatic tumor burden, and doxorubicin-cyclophosphamide chemotherapy. Cancer Immunol Immunother. 2009;58:49-59.

15. Polat MF, Taysi S, Polat $\mathrm{S}$, et al. Elevated serum arginase activity levels in patients with breast cancer. Surg Today. 2003;33:655-661.

16. de Souza AP, Bonorino C. Tumor immunosuppressive environment: effects on tumor-specific and nontumor antigen immune responses. Expert Rev Anticancer Ther. 2009;9:1317-1332.

17. Domschke C, Schuetz F, Ge Y, et al. Intratumoral cytokines and tumor cell biology determine spontaneous breast cancer-specific immune responses and their correlation to prognosis. Cancer Res. 2009;69:8420-8428.

18. Heldin CH, Landström M, Moustakas A. Mechanism of TGF-beta signaling to growth arrest, apoptosis, and epithelial-mesenchymal transition. Curr Opin Cell Biol. 2009;2:166-176.

19. Wrzesinski SH, Wan YY, Flavell RA. Transforming growth factor- $\beta$ and the immune response: implications for anticancer therapy. Clin Cancer Res. 2007;13:5262-5270.

20. Crane CA, Han SJ, Barry JJ, et al. TGF-beta downregulates the activating receptor NKG2D on NK cells and CD8+ T cells in glioma patients. Neuro Oncol. 2010;12:7-13.

21. Tian M, Schiemann WP. The TGF- $\beta$ paradox in human cancer: an update. Future Oncol. 2009;5:259-271.

22. Massague J, Gomis RR. The logic of TGF- $\beta$ signaling. FEBS Lett. 2006;580:2811-2820.

23. Massague J, Seoane J, Wotton D. Smad transcription factors. Genes Dev. 2005; 19:2783-2810.

24. Runyan CE, Hayashida T, Hubchak S, Curley JF, Schnaper HW. Role of SARA (SMAD anchor for receptor activation) in maintenance of epithelial cell phenotype. J Biol Chem. 2009;284:2518-2519.

25. Chaudhury A, Hussey GS, Ray PS, Jin G, Fox PL, Howe PH. TGF- $\beta$ mediated phosphorylation of hnRNP E1 induces EMT via transcriptselective translational induction of Dab2 and ILEI. Nat Cell Biol. 2010; 12:286-293.

26. Hussey GS, Chaudhury A, Dawson AE, et al. Identification of an mRNP complex regulating tumorigenesis at the translational elongation step. Mol Cell. 2011;41:419-431.
OncoTargets and Therapy

\section{Publish your work in this journal}

OncoTargets and Therapy is an international, peer-reviewed, open access journal focusing on the pathological basis of all cancers, potential targets for therapy and treatment protocols employed to improve the management of cancer patients. The journal also focuses on the impact of management programs and new therapeutic agents and protocols on

\section{Dovepress}

patient perspectives such as quality of life, adherence and satisfaction. The manuscript management system is completely online and includes a very quick and fair peer-review system, which is all easy to use. Visit http://www.dovepress.com/testimonials.php to read real quotes from published authors. 